\title{
An Analysis of Conflict Styles in Terms of Various Variables among Athletes Participated in Turkey Inter-Unıversities Wushu Championship
}

\author{
Zühal Kılınç ${ }^{\circledR}$ \\ Nevzat Dinçer ${ }^{2}$ \\ Batman University, Batman, Turkey \\ 'Email:zuhalkikinc14@gmail.comTel:05320511414 \\ 2Email:nevzamail.@gmail.com Tel:05425950749
}

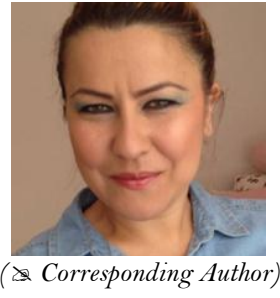

Abstract

In this paper, the conflict styles of 288 athletes participated in Turkey Inter-Universities Wushu Championship in Antalya in the academic year 2017-2018 were evaluated. The research presents the significance for revealing the athletes' conflict styles with their families, trainers and teammates and creating solutions. The questionnaire was used as a data collection tool in the research. This scale was adapted from the measurement used in the undergraduate students by Önder (2008). The athletes' conflict styles were determined with their responses to the questions as $(2,02 \pm 1,07)$ in the vertical conflict on average. In the horizontal conflict and vertical conflict sub-dimensions, the athletes were seen to experience less conflicts $(1,90 \pm, 985)$. The significant differences were found between the vertical conflict and horizontal conflict sub-dimensions in the variables of age, educational back ground, undergraduate year and domicile. In accordance with the gender variable, a significant difference was found in the horizontal conflict sub-dimension. The female athletes were considered to experience horizontal conflicts less than the male ones among themselves. This paper has great importance since it keeps light on the managers and the athletes. In conclusion, the athletes participated in the vertical and horizontal conflict subdimensions less. This means that the athletes have positive approaches to conflicts, and that they are well-intentioned in conflict management. It is possible to say that conlicts are experienced less by them since sportive performance makes positive effects.

Keywords: Conflict, Athlete, Struggle athlete, University, Education, Coach

Citation | Zühal Kılınç; Nevzat Dinçer (2019). An Analysis of Conflict Styles in Terms of Various Variables among Athletes Participated in Turkey Inter-Unıversities Wushu Championship. Asian Journal of Education and Training, 5(1): 140-145.

\section{History:}

Received: 7 November 2018

Revised: 20 December 2018

Accepted: 14 January 2019

Published: 2 February 2019

Licensed: This work is licensed under a Creative Commons

Attribution 3.0 License (cc) $\mathbf{E}$

Publisher: Asian Online Journal Publishing Group
Contribution/Acknowledgement: Both authors contributed to the conception and design of the study.

Funding: This study received no specific financial support.

Competing Interests: The authors declare that they have no conflict of interests.

Transparency: The authors confirm that the manuscript is an honest, accurate, and transparent account of the study was reported; that no vital features of the study have been omitted; and that any discrepancies from the study as planned have been explained.

Ethical: This study follows all ethical practices during writing.

\section{Contents}

1. Introduction

2. Method

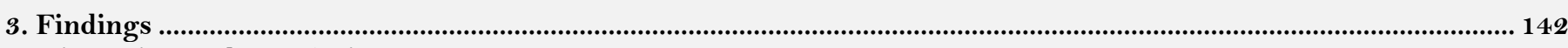

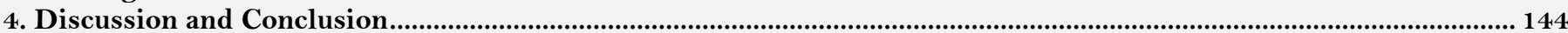

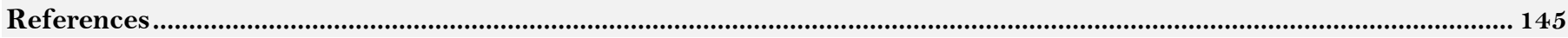




\section{Introduction}

In literature, scientists who have been working in the field of conflicts, have presented different definitions for conflicts. Conflicts are defined as "events which result from working problems in individuals or groups coming together and cause normal activities take a pause or let ones become involved in complexity" (Eren, 2012). Wilmot and Hocker describe conflicts in such a way: persons sometimes determine inconsistent aims and insufficient resources to achieve their goals, struggles between two parties dependent on each other resulting from others' interventions are called as conflicts (Hocker and Wilmot, 2001). According to Rahim (2002) conlicts are defined as a process with lack of harmony, incompatibility, discordance between people. It is inevitable to have conflicts in environments people gather, it is necessary to think these ones as ordinary issues. Because each person's personal features, habits, life satisfaction levels and expectations vary from each other. Conflicts have positive results in working environments at a certain level. However, when conflicts are intensive and frequent, they damage to organizations and workers in a long term (Güllü, 2018).

When the reasons, intensity and relevant units of conflicts are determined to have an effective and efficient conflict management process in enterprises, they will make contributions to the effective management of the relevant conflict process (Topaloğlu and Avc1, 2008). When the relevant process is manipulated in an organization well, conflicts are inclined to increase the organizational success. In this regard, undesirable interactions for conflicts or any organization may be reasons of the organizational amendments. If there is not any organizational conflict, the structural stability occurs. Reductions in the organizational movement of an enterprise may cause slowness in the development of managers' capabilities, the absence of creativity in time. But conflicts must be kept under the control and planned for being used as a management instrument. Similarly, conflicts can be in controlled ways, as well as out of the control (Karip, 1999).

Conflicts are divided in an organization into three groups including horizontal conflicts, vertical conflicts and a chain of command-staff conflicts (Koçel, 2001). Horizontal conflict is a type of conflicts between the persons at the same grade or at the same departments (e.g. production and sales departments). This type of conflicts results from incompatible purposes, insufficient resources and relation problems between the persons (Solmuş, 2001). Workers in each department affect each other to fulfill common objectives. This interaction may cause conflicts by revealing the competition between the departments. If this competition helps to achieve goals, conflicts show their positive effects, if it obstructs or delays achieving goals, conflicts show their negative effects as well (Erdoğan, 1999). Vertical conflict is described as a disagreement situation between the individuals at different grades in an organization. This type of conflicts is seen among the subordinate ones and the superordinate ones. Moreover, when the superordinate ones domineer, force, despise and reprimand the subordinate ones, the subordinate ones resist to these situations, conflicts occur (Şimşek and Kıngır, 2006). When an individual thinks about getting a raw deal, it may let the one have hostile attitudes to the superordinate ones in the system of hierarchy. If the superordinate management is hard to have a higher position in wage and prestige levels for the subordinate ones, relations may cause tension and then turn into conflicts, in this way conflicts are urgent (Tosun, 1981). $A$ chain of command-staff conflicts is regarded as conflicts between the managers and the staff since they have different personalities, different attitudes and values. In some situations, the managers think that their staff weaken their own authorities, so they can intervene in their staff's fields. Such situations sometimes arise conflicts between two parties (Erdoğan, 1999).

\section{Method}

\subsection{Scope and Sample}

The scope of the research consisted of 385 athletes from 35 universities participated in the Turkey InterUniversities Wushu Championship in Antalya in the academic year 2017-2018. The sample of the research also consisted of 288 athletes voluntarily participated here.

\subsection{Data Collection Tool}

As a data collection tool, the questionnaire was used in the research. The questionnaire form consisted of two parts. The first part involved the demographical questions to determine their personal information. The second part also involved the scale of conflict styles to determine the conflict styles with their teammates and trainers. This scale was adapted from a scale which was used in the undergraduate students by Önder (2008). This scale consisted of 17 items, was adjusted as a 5 point likert scale. While the positive questions were given points as Disagree (1), Less Agree (2), Sometimes Agree (3), Mostly Agree (4), Always Agree (5), the negative questions were given points vice versa. 17 questions were asked about determining the students' conflict types and the questions were given at random. 11 questions in this part $(1,3,4,6,8,9,11,13,14,16,17)$ represented the vertical conflict type, 6 of them $(2,5,7,10,12,15)$ represented the horizontal conflict type as well. It was made up of two sub-dimensions. The reliability of data was tested with the Cronbach Alpha coefficient. The internal consistency reliability coefficient of the questionnaire was estimated as 0,82 .

\subsection{Data Collection}

This research was based on the Turkey Inter-Universities Wushu Championship in Antalya in the academic year 2017-18. 385 athletes from 35 universities took part in the championship. 288 athletes were available there. The questionnaire was applied to the athletes by the researcher. Incomplete, torn and incorrect questionnaires were excluded from the research. 288 questionnaires were included in assessment in total.

\subsection{Data Analysis}

The statistical analyses were done using the SPSS for Windows 16,0 package program me. To determine the differences between the relevant points from the research, within the comparison of the quantitative data for two groups, Independent Samples T test for the independent samples in inter-groups comparisons and One Way Anova 
test for ones more than two groups were utilized. "Tukey" test was used to find out from which groups the difference between the groups resulted. The results were analyzed based on the significance level $p<0,05$.

\section{Findings}

\begin{tabular}{l|l|l}
\multicolumn{3}{c}{ Table-1. The Distribution of Participants' Personal Features } \\
\hline Gender & $\mathbf{n}$ & $\mathbf{\%}$ \\
\hline Male & 185 & 64,4 \\
\hline Female & 103 & 35,6 \\
\hline Age & $\mathbf{n}$ & $\mathbf{\%}$ \\
\hline Aged 18-20 & 88 & 30,4 \\
\hline Aged 21-23 & 67 & 23,2 \\
\hline Aged 24-26 & 86 & 29,8 \\
\hline Aged 27-29 & 23 & 8,0 \\
\hline Aged 30 and over & 24 & 8,3 \\
\hline Which Grade & $\mathbf{n}$ & $\mathbf{\%}$ \\
\hline Grade 1 & 116 & 40,1 \\
\hline Grade 2 & 78 & 27,0 \\
\hline Grade 3 & 53 & 18,3 \\
\hline Grade 4 & 41 & 14,2 \\
\hline Undergraduate Year & $\mathbf{n}$ & $\mathbf{\%}$ \\
\hline 1-2 & 79 & 27,3 \\
\hline 3-4 & 91 & 31,5 \\
\hline $5-6$ & 42 & 14,5 \\
\hline 7 and over & 76 & 26,3 \\
\hline Who Live With You & $\mathbf{n}$ & $\%$ \\
\hline Family & 46 & 15,9 \\
\hline Club Members & 35 & 12,1 \\
\hline Housemate & 189 & 65,4 \\
\hline Alone & 18 & 6,2 \\
\hline One Interested in Family & $\mathbf{n}$ & $\mathbf{\%}$ \\
\hline Yes & 103 & 35,6 \\
\hline No & 185 & 64,4 \\
\hline Total & 288 & $\% 100$ \\
\hline & & \\
\hline
\end{tabular}

According to Table 1, $185(64,4 \%)$ of the participants were females, $103(35,6 \%)$ of the participants were males.

The participants were aged $18-20$ in 88 persons (30,4\%), $21-23$ in 67 persons (23,2\%), 24-26 in 86 persons $(29,8 \%), 17-29$ in 23 persons $(8,0 \%), 30$ and over in 24 persons $(8,3 \%)$ on the age variable. In accordance with the participants' grade variable, 116 persons $(40,1 \%)$ from the grade 1,78 persons $(27,0 \%)$ from the grade 2,53 persons $(18,3 \%)$ from the grade 3,41 persons $(14,2 \%)$ from the grade 4 participated, when their undergraduate years were analyzed, 79 persons $(27,3 \%)$ were the participants with $1-2$ years of undergraduate, 91 persons $(31,5 \%)$ were the participants with 3-4 years of undergraduate, 42 persons (14,5\%) were the participants with 5-6 years of undergraduate, 76 ones $(26,3 \%)$ were the participants with 7 years and over of undergraduate. About who live with you, the athletes living with their families were of 46 persons $(15,9 \%)$, the participants staying at club facilities were of 35 persons $(12,1 \%)$, the ones staying with their housemates were of 189 persons $(65,4 \%)$ and the participants staying alone were of 18 persons $(6,2 \%)$, the family members of the participants interested in sport were of 103 persons $(35,6 \%)$, the family members of the participants not interested in sport were of 185 persons $(64,4 \%)$.

Table-2. The Descriptive Statistical Results of Participants' Conflict Style Levels

\begin{tabular}{|c|c|c|c|}
\hline Items & \multirow{12}{*}{ 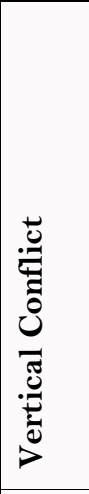 } & Mean & $S S$ \\
\hline 1. My trainer values my opinions. & & 1,55 & ,686 \\
\hline 3. My trainer benefits from the one's authority to domineer me. & & 1,77 & 1,02 \\
\hline 4. My trainer respects to me as an individual. & & 1,69 &, 837 \\
\hline 6. My trainer always supports me to develop myself. & & 2,07 & 1,10 \\
\hline 8. My trainer's expectations conflict with with my expectations. & & 2,22 & 1,20 \\
\hline 9. My trainer gives importance to my desires. & & 2,07 & 1,17 \\
\hline 11. My trainer is aware of the one's responsibilities. & & 1,79 & ,997 \\
\hline 13. I have a healthy relationship with my trainer. & & 2,05 & 1,05 \\
\hline 14. My trainer is professional and the one treats me professionally and neutrally in case of any event. & & 1,92 & ,992 \\
\hline 16. I have opinions different from my trainer. & & 2,37 & 1,26 \\
\hline 17. My trainer is unconcerned with my problems. & & 2,72 & 1,50 \\
\hline Total & \multirow{7}{*}{ 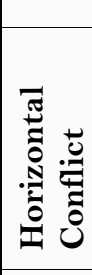 } & 2,02 & 1,07 \\
\hline 2. My teammates make effort to find a common way even if they have different opinions. & & 1,65 &, 815 \\
\hline 5. My teammates share their own information to succeed in lessons. & & 1,62 & ,693 \\
\hline 7. My teammates' priorities differ from my priorities. & & 1,94 & 1,11 \\
\hline 10. My teammates respect to me as an individual. & & 2,09 & ,996 \\
\hline 12. My teammates are respectful to different opinions. & & 1,94 & 1,16 \\
\hline 15. I have a healthy relationship with my teammates. & & 2,16 & 1,14 \\
\hline Total & & 1,90 & ,985 \\
\hline
\end{tabular}

In accordance with Table 2 , the general average of the athletes' responses to the questions about the conflict styles was estimated as $(2,02 \pm 1,07)$ in the vertical conflict. The athletes took part in the vertical conflict sub- 
dimension too little. When examined about the items, the highest average was observed as $(2,72 \pm 1,50)$ within the item "My trainer is unconcerned with my problems". The lowest average was determined as $(1,55 \pm, 686)$ within the item "My trainer values my opinions".

Within the horizontal conflict sub-dimension, the athletes took part in conflicts too little $(1,90 \pm, 985)$. When the athletes' responses were analyzed, the highest average was $(2,16 \pm 1,14)$ within the item "I have a healthy relationship with my teammates", the lowest average was $(1,65 \pm, 815)$ within the item "My teammates share their own information to succeed in lessons"

Table-3. The Anova Results of Participants' Relations in Accordance with Age Variable

\begin{tabular}{|c|c|c|c|c|c|c|c|}
\hline Sub-Dimensions & Age & S.T. & df & S.O. & $\mathbf{F}$ & p & Difference \\
\hline \multirow{3}{*}{ Vertical Conflict } & Inter-Groups & 5,06 & 4 & 1,26 & \multirow{3}{*}{4,71} & \multirow{3}{*}{$* 0,00$} & \multirow{3}{*}{$\begin{array}{l}1-5 \\
3-5\end{array}$} \\
\hline & In-Group & 76,05 & 284 &, 26 & & & \\
\hline & Total & 81,12 & 288 & & & & \\
\hline \multirow{3}{*}{ Horizontal Conflict } & Inter-Groups & 3,93 & 4 & ,98 & \multirow{3}{*}{2,90} & \multirow{3}{*}{ *0,02 } & \multirow{3}{*}{$\begin{array}{l}1-4 \\
2-4\end{array}$} \\
\hline & In-Group & 95,88 & 284 & ,33 & & & \\
\hline & Total & 99,81 & 288 & & & & \\
\hline
\end{tabular}

At Table 3, the Anova results were given about the athletes' age variable. When the age variable was examined, a significant difference was observed in the vertical conflict sub-dimension. When looked at the difference, there were significant differences between the athletes aged 30 and over and the athletes aged 18-20 and 24-26. The participant athletes aged 30 and over were considered to experience the vertical conflict more rather than the athletes aged 18-20 and 24-26.

When the horizontal conflict sub-dimension was analyzed, a significant difference was found in the age variable. When looked at the difference, the athletes aged 27-29 were considered to experience the horizontal conflict with the athletes aged 18-20 and 21-23. When the athletes get older, they are deemed to have problems with the athletes involved in the middle age group.

\begin{tabular}{|c|c|c|c|c|c|c|c|}
\hline Sub-Dimensions & Educational Background & S.T. & Df & S.O. & $\mathbf{F}$ & $\mathbf{P}$ & Difference \\
\hline \multirow[t]{2}{*}{ Vertical Conflict } & Inter-Groups & 5,36 & 4 & 1,78 & 6,70 & *0,00 & $\begin{array}{l}1-3 \\
2-3\end{array}$ \\
\hline & In-Group & 75,75 & 284 & ,26 & & & \\
\hline \multirow{4}{*}{$\begin{array}{l}\text { Horizontal } \\
\text { Conflict }\end{array}$} & Total & 81,12 & 288 & & & & \\
\hline & Inter-Groups & 96,28 & 4 & 1,17 & 3,47 & $* 0,01$ & $\begin{array}{l}1-3 \\
2-3\end{array}$ \\
\hline & In-Group & 99,81 & 284 & ,33 & & & \\
\hline & Total & 96,28 & 288 & & & & \\
\hline
\end{tabular}

At Table 4, the Anova results were given in accordance with the participants' grade variable. When the athletes' grade variables was analyzed, the significant differences were found between the vertical conflict and the horizontal conflict as both sub-dimensions. When the differences were examined, the vertical conflict and the horizontal conflict sub-dimensions were experienced between the athletes studying at grade 3 and the athletes studying at grade 1 and grade 2 . This means that when the participants' grades go ahead, they are deemed to have problems with both the ones in their own environment and their friends at upper grades and lower grades.

Table-5. The Anova Results of Participants in Accordance with Undergraduate Year

\begin{tabular}{|c|c|c|c|c|c|c|c|}
\hline .Sub-Dimensions & Undergraduate Year & S.T. & df & S.O. & $\mathbf{F}$ & $\mathbf{P}$ & Difference \\
\hline \multirow{3}{*}{ Vertical Conflict } & Inter-Groups & 2,73 & 4 & 0,91 & \multirow{3}{*}{3,30} & \multirow{3}{*}{ *0,02 } & \multirow{3}{*}{$\begin{array}{l}1-3 \\
1-4\end{array}$} \\
\hline & In-Group & 78,38 & 284 & 0,27 & & & \\
\hline & Total & 81,12 & 288 & & & & \\
\hline \multirow{3}{*}{ Horizontal Conflict } & Inter-Groups & 4,57 & 4 & 1,52 & \multirow{3}{*}{4,54} & \multirow{3}{*}{$* 0,00$} & \multirow{3}{*}{$1-3$} \\
\hline & In-Group & 95,23 & 284 & 0,33 & & & \\
\hline & Total & 99,81 & 288 & & & & \\
\hline
\end{tabular}

*P<0.05 1: 1-2 years 2: 3-4 years, 3: 5-6 years,4: 7 years and over

At Table 5, the participants' Anova results were given about the variable of undergraduate year. When the athletes' undergraduate year was examined, there were significant differences both in the vertical and horizontal sub-dimensions. When the differences were analyzed, there were significant differences between the athletes having 1-2 years of undergraduate and the athletes having 5-6 years of undergraduate, in both dimensions. There was a significant difference in the vertical conflict sub-dimension between the participants having 1-2 years of undergraduate and the athletes having 7 years of undergraduate and over. When the participant athletes had more experiences in their own sport branches, they had the vertical conflict more with the athletes who started sport in recent times, they had the horizontal conflict less with the athletes in their undergraduate group.

At Table 6, the Anova results were given about the participants' domicile situations. In accordance with the athletes' domicile situations, there were significant differences between the vertical conflict and horizontal conflict sub-dimensions. Looking at the differences, there were significant differences in the vertical sub-dimension between the participants living with their families, the ones living with their housemates and the ones staying at home alone, the athletes staying at club facilities, the ones staying with their housemates and the athletes staying at home alone. The athletes living with their families and staying at club facilities were considered to have conflicts with other persons staying at home alone or the ones living with their friends. 
Table-6. The Anova Results of Participants in Accordance with Domicile Situations

\begin{tabular}{|c|c|c|c|c|c|c|c|}
\hline Sub-Dimensions & Residence Status & S.T. & Df & S.O. & $\mathbf{F}$ & p & Difference \\
\hline \multirow[t]{2}{*}{ Vertical Conflict } & Inter-Groups & 6,82 & 4 & 2,27 & 8,69 & * 0,00 & \multirow{3}{*}{$\begin{array}{l}1-3 \\
1-4 \\
2-3 \\
2-4\end{array}$} \\
\hline & In-Group & 74,29 & 284 & 0,26 & & & \\
\hline \multirow[t]{4}{*}{$\begin{array}{l}\text { Horizontal } \\
\text { Conflict }\end{array}$} & Total & 81,12 & 288 & & & & \\
\hline & Inter-Groups & 2,76 & 4 & 0,92 & 2,70 & * 0,04 & \multirow{3}{*}{$3-4$} \\
\hline & In-Group & 97,04 & 284 & 0,34 & & & \\
\hline & Total & 99,81 & 288 & & & & \\
\hline
\end{tabular}

When examined the horizontal conflict, there was a significant difference between the ones staying with their housemates and the ones staying at home alone. Looking at the difference, the participant athletes living with their house mates experience problems at home or at school.

Table-7. The T-Test Results of Participants in Accordance with Gender Variable

\begin{tabular}{|c|c|c|c|c|c|c|}
\hline & Gender & $\mathbf{N}$ & Ort & $\mathbf{S S}$ & $\mathbf{T}$ & p \\
\hline \multirow{2}{*}{ Vertical Conflict } & Male & 185 & 2,03 &, 517 & \multirow{2}{*}{0,85} & \multirow{2}{*}{0,39} \\
\hline & Female & 103 & 1,98 &, 556 & & \\
\hline \multirow{2}{*}{ Horizontal Conflict } & Male & 185 & 1,96 &, 565 & \multirow{2}{*}{2,61} & \multirow{2}{*}{ * 0,00} \\
\hline & Female & 103 & 1,77 & ,614 & & \\
\hline
\end{tabular}

According to Table 7, there was not a significant difference in the vertical conflict sub-dimension among the conflict styles in accordance with the participants' gender variable $(t=0,85 ; \mathrm{p}>0,05)$. In the horizontal conflict subdimension, there was a significant difference in the gender variable $(t=2,61 ; \mathrm{p}<0,05)$. Looking at the difference, the female athletes experience the horizontal conflict less than the male ones among themselves.

\begin{tabular}{l|l|l|l|l|l|l}
\multicolumn{1}{c}{ Table-8. The T-Test Results of Participants in Accordance with Family Members Interested in Sport Variable } \\
\hline & Family Members Interested in Sport & N & Ort & SS & T & p \\
\hline Vertical Conflict & Yes & 90 & 2,05 &, 523 & 0,79 & 0,42 \\
\hline & No & 198 & 2,00 &, 534 & & \\
\hline Horizontal Conflict & Yes & 90 & 1,90 &, 591 & 0,08 & 0,93 \\
\hline & No & 198 & 1,89 &, 589 & & \\
\hline
\end{tabular}

At Table 8, the t-test results from the participants were given in accordance with the variable of family members interested in sport. There was not a significant difference in the vertical conflict sub-dimension among the conflict styles $(t=0,79 ; p>0,05)$. There was not a significant difference in the horizontal conflict sub-dimension in accordance with the gender variable $(t=0,08 ; p>0,05)$.

\section{Discussion and Conclusion}

This research was done to reveal the conflict styles of the athletes participated in the Turkey inter-universities Wushu championship. The athletes were considered to experience conflicts due to some variables. The athletes slightly participated in the vertical and horizontal conflict sub-dimensions.

A significant difference was seen in the vertical conflict sub-dimension among the athletes aged 30 and over, living with their families and having 7 years of undergraduate and over. The athletes who became older, developed themselves in sport and lived with their families, were suggested to have more conlicts with their trainers or their managers. In a study by Sahin et al. (2014) especially the disabled athletes having professional experience of 1-5 and 11-15 years were emphasized to have the vertical conflicts among themselves. This study supports our findings.

When examined the horizontal conflict sub-dimension, there was a significant difference in the age variable. When examined about the difference, the athletes aged 27-29, the athletes aged 18-20 and 21-23 were experienced the horizontal conflicts. When the athletes became older, they could have problems with the athletes included in the middle age group. When the participant athletes got older in their sport branch, they were mentioned to experience the horizontal conflicts with the athletes in their undergraduate group less. A study by Sahin et al. (2014) showed that there was a very significant difference between the disabled athletes having 1-5 years of professional experience and the disabled athletes having 11-15 years of professional experience in the horizontal conflict sub-dimension resulting from the analysis of the professional experience variable. The disabled athletes having 11-15 years of professional experience had more conflicts with their teammates rather than the disabled athletes having professional experience less. This research shows parallelism with our research findings.

When the grade variable of the athletes was assessed, significant differences were seen in both sub-dimensions including the vertical conflict and the horizontal conflict. When the differences were examined, the vertical and horizontal conflicts were observed in the athletes studying at the grade 3 with the athletes studying at the grade 1 and grade 2. This means that the participants have problems with both the ones in class environments and their friends in lower grades and upper grades when the participants' grades were proceeded.

When the difference was investigated, the female athletes experienced less conflicts among them seves rather than the male ones. Other researches indicated that relation was distinguished in the conflict styles on gender. Sevim (2005) determined that the female students were more positive than the male ones, they had constructive solution skills for conflicts. Önder (2008) also suggested that the male students used more domineering styles rather than the female students in his research about the gender variable and the conflict styles. Uğurlu (2001) found that there were significant differences in all of conflict management styles used in accordance with the teachers' gender by principals. There were not significant differences in the gender variable, so this clarifies that 
sport makes positive contributions to conflicts. Many researches mentioned about the positive effects of sport. Kilınç et al. (2015) studied on the conflict management styles among the athletes with hearing loss and physical disabilities living in the Southeast Anatolian Region and found no relation between the gender and the conflict styles.

Based on the assumption that the athletes involved in the Turkey Inter-Universities Wushu Championship experienced the conflicts, this research was done to determine their own conflict styles. As a result, the athletes took part in the vertical and horizontal conflict sub-dimensions too little. This means that the athletes positively approach conflicts and they are well-intentioned to manage conflicts. Since sportive performance creates positive effects, it is possible to have less conflict.

In summary, positive or negative attitudes acquired by individuals affect relations between persons. That's why, it will be useful for making necessary arrangements in educational programs at universities, giving student's education about conflicts and its management in order to have positive attitudes about conflicts and conflict management for students. Making orientation programs for students by management units at universities to have healthy relations with their friends and universities will contribute to have conflicts less.

\section{References}

Erdoğan, İ., 1999. Organizational behaviour in business management. Faculty of Management Publications İstanbul University No: 266. İstanbul: Business Economics Institute Edition, 2(158).

Eren, E., 2012. Organizational behavior and management psychology. 16th Edn., İstanbul: Beta Edition.

Güllü, S., 2018. Mediating role of organizational health about effects of leader-member interaction on working life quality and antiproductivity work behaviours: A sample of sport enterprises. İstanbul University Institute of Health Sciences, Department of Sport Management Sciences. Doctorate Thesis. İstanbul.

Hocker, J.L. and W.W. Wilmot, 2001. Interpersonal conflict. Benchmark Boston, MA: McGraw-Hill.

Karip, E., 1999. Conflict management. Ankara: Pegem Press.

Kılınç, Z., B. Gürer, H.M. Şahin and U. Gülnar, 2015. Evaluation of conflict management styles used by hearing impaired and physically handicapped athletes (Sample of Southeastern Anatolia Region). Kastamonu University Journal of Faculty of Economics and Administrative Sciences, 6(6): 52-60.

Koçel, T., 2001. Business administration, management and organization, organizational behaviours, classical-modern-contemporary and current approaches. İstanbul: Beta Publications, 8.

Önder, E., 2008. Conflicts experienced by undergraduate students and conflict management styles (Sample of Süleyman Demirel University). Süleyman Demirel University Institute of Social Sciences, Department of Education Management Supervision Planning and Economy, Master's Thesis Isparta.

Rahim, A.M., 2002. Toward a theory of managing organizational conflict. International Journal of Conflict Management, 13(3): 206-235. Available at: https://doi.org/10.1108/eb022874.

Sahin, H.M., Z. Kılınç, B. Gürer and O. Hacıoğlu, 2014. Investigation of some types of conflict experienced by the disabled and the physically disabled athletes in terms of some demographic variables. Kastamonu University Journal of Faculty of Economics and Administrative Sciences, 5(2): 27-36.

Sevim, S.A., 2005. Approach styles of university students for conflicts. Eurasian Journal of Educational Research, $21(5)$ : $223-233$.

Şimşek, M.Ş. and S. Kıngır, 2006. Chosen contemporary management instruments. Ankara: Nobel Press.

Solmuş, T., 2001. Interpersonal and intergroup conflicts and conflict management in organizations. Turkish Psychology Newsletter, 20: 4049 .

Topaloğlu, C. and U. Avcı, 2008. Conflict, reasons and management: Evaluation of a manager's viewpoints in hotel enterprises. Süleyman Demirel University IIBF Journal, 13(2): 75-92.

Tosun, M., 1981. Organizational efficiency. Ankara: Turkey and Middle-East Public Administration Press.

Uğurlu, F., 2001. Conflict management styles of primary and secondary school directors. Dokuz Eylül University. Institute of Education Sciences, Unpublished Master's Thesis, İzmir. 